\title{
The importance of offshore areas in southern Öresund, Sweden, for staging and wintering sea ducks
}

\author{
Betydelsen av yttre havsområden i södra svenska Öresund för rastande och \\ övervintrande havsdykänder
}

MARTIN GREEN \& LEIF NILSSON

\begin{abstract}
The occurrence of wintering and spring-staging sea ducks in the southern part of Swedish Öresund was surveyed from air and ship during the period 2001-2011. Altogether 22 air and 20 boat surveys were made during the months November-May and here we present the results regarding five commonly recorded sea ducks. We present the numbers recorded and the general time pattern of occurrence during winter and spring in the area. Recorded numbers are then used for evaluating the importance of the area, both in relation to national wintering totals as well as to international (Baltic) totals. Southern Swedish Öresund is of no larger importance for Long-tailed Duck Clangula hyemalis in winter and spring. The area
\end{abstract}

is however of national importance for both Velvet Scoter Melanitta fusca and Common Scoter Melanitta nigra in winter. Peak numbers of Common Scoters do also reach international importance. Southern Swedish Öresund is of large national and international importance for both wintering and spring-staging Eider Somateria mollissima and Red-breasted Merganser Mergus merganser.

Martin Green and Leif Nilsson, Department of Biology, Ecology Building, 22362 Lund, Sweden; E-mail: Martin. Green@biol.lu.se

Received 27 October 2014, Accepted 25 February 2015, Editor: J. Waldenström

\section{Introduction}

Southern Öresund is an important staging and wintering area for large numbers of waterfowl. Saltholm (on the Danish side) and Foteviken-Falsterbo (in Sweden) are designated Special Bird Protection Areas (SPA) under the Birds' directive of the European Union (2009/147/EG). Both these areas are also designated areas of international importance under the Ramsar convention (www. ramsar.org). Other parts of Öresund, e.g. Lommabukten and Lundåkrabukten further north along the Swedish coast are also important for different wetland species and also these, or parts of these, are designated SPA under the Birds' directive as well as Ramsar areas. Both these areas regularly hold bird numbers fulfilling the criteria for international importance.

While the importance of the near-shore areas of Öresund for waterfowl is well known (Nilsson 1996, Nilsson 2008), much less information has been collected regarding the offshore parts. Here we use data from a monitoring program around the Lillgrund wind farm (Green \& Nilsson 2006, Nilsson \& Green 2011) in order to describe the numbers of sea ducks using the offshore parts of southern Swedish Öresund. Low numbers of these species are regularly seen from the coasts, but the vast majority of all individuals using the area are to be found at longer distances $(>2 \mathrm{~km})$ from the coast.

The Lillgrund wind farm was constructed in 2007 and consists of $482.3 \mathrm{MW}$ turbines (Vattenfall Vindkraft 2009; or see www.vattenfall.se/sv/lillgrundvindkraftpark.htm for details). The wind farm is situated in the central parts of southern Öresund $\left(55,5^{\circ} \mathrm{N} ; 12,8^{\circ} \mathrm{E}\right)$, the closest turbine to the Swedish coast is about five $\mathrm{km}$ off-shore from the harbour of Klagshamn. From the westernmost turbine it is about $20 \mathrm{~km}$ to the closest part of the Danish coast (Figure 1). A monitoring programme ran during the ten year period 2001-2011 in order to study the possible impact of the wind farm on the bird fauna using and migrating through the area (Nilsson 2001, Green \& Nilsson 2006, Nilsson \& Green 2011). Field work was done both before (2001-2006) and after (2007-2011) the construction of the wind farm. Monitoring of sea ducks was done by aerial and boat surveys, and covered both the possible impact area of the wind farm as well as reference areas. Hence, the monitoring included a large part of the Swedish 


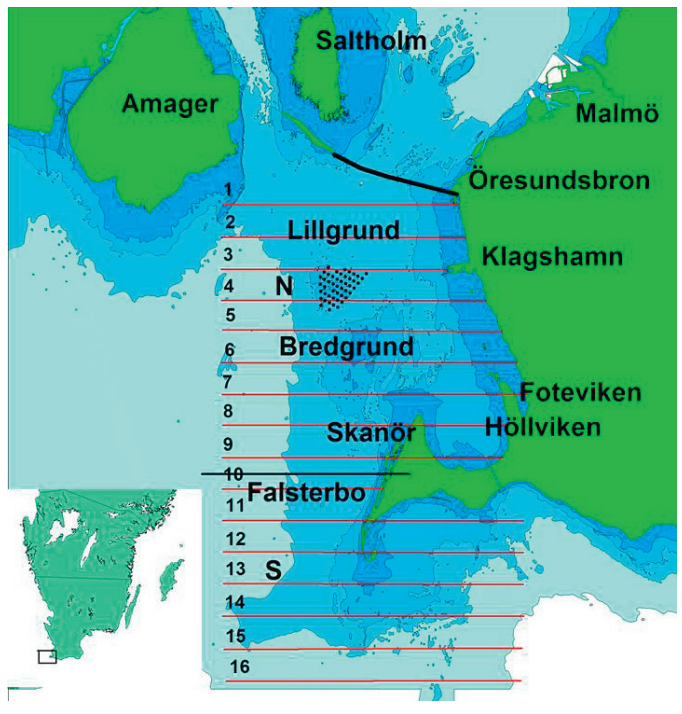

Figure 1. Map of the southern part of Öresund and waters south of Falsterbo with the aerial survey lines (1-16). $\mathrm{N}=$ northern part and $\mathrm{S}=$ southern part. Water depths are shown with different grades of blue: 0-3m (darkest), 3-6 m, 6-10 m and 10-20 m (lightest). Deeper areas in the south are shown in white. Wind turbines at Lillgrund are shown with black dots. Inserted map of south Sweden showing the position of the study area.

Karta över södra Öresund och farvattnen runt Falsterbo med de standardiserade flyginventeringslinjerna markerade (1-16). $N=$ norra delen, $S=$ södra delen. De olika djupnivåerna i södra Öresund visas med olika mörka blå nyanser: 0-3 m (mörkast), 3-6 m, 6-10 m samt 10-20 m (ljusast blått). Djupare områden saknar färg på kartan. Vindkraftverken vid Lillgrund visas med svarta punkter. Infälld en karta över södra Sverige visar läget av undersökningsområdet.

side of offshore southern Öresund.

For the evaluation of the possible impacts on birds from the wind farm we refer to reports from the monitoring program (Green \& Nilsson 2006, Nilsson \& Green 2011). In short, the impacts on sea ducks were of marginal importance. Bird numbers using the wind farm area (i.e. the area in between, and close to, the turbines) decreased during the first years of operation, but numbers using the whole area were largely unaffected. There were also some signs of habituation to the wind farm after the initial years (Nilsson \& Green 2011).

Here we do not mention these results any further, but focus on numbers and distribution of sea ducks within the whole study area. Other species apart from the ones covered here were registered as well, especially in near-shore areas. For full details about the numbers and distribution of these, see Nilsson \& Green (2011).

\section{Study area}

The study area covered the major parts of the Swedish and adjacent Danish waters of southern Öresund. The total study area was about $700 \mathrm{~km}^{2}$ (Figure 1). Offshore parts of southern Öresund have water depths ranging from just a few $m$ down to about $15 \mathrm{~m}$. There are several shallow parts, with water depths between two and six m, within the study area. Among these Lillgrund, west of Klagshamn, where the wind farm is now in operation, Bredgrund, between Lillgrund and the Falsterbo peninsula, and the shallows west and south of the Falsterbo peninsula should be mentioned (Figure $1)$. The entire study area has a water depth of less than $20 \mathrm{~m}$, with approximately $30 \%$ shallower than six $\mathrm{m}$.

The full study area was only covered during aerial surveys. During boat surveys a smaller part of the offshore parts on the Swedish side of southern Öresund, north of the Falsterbo peninsula was covered (Figure 2). For comparing bird numbers using different parts of off-shore southern Öresund

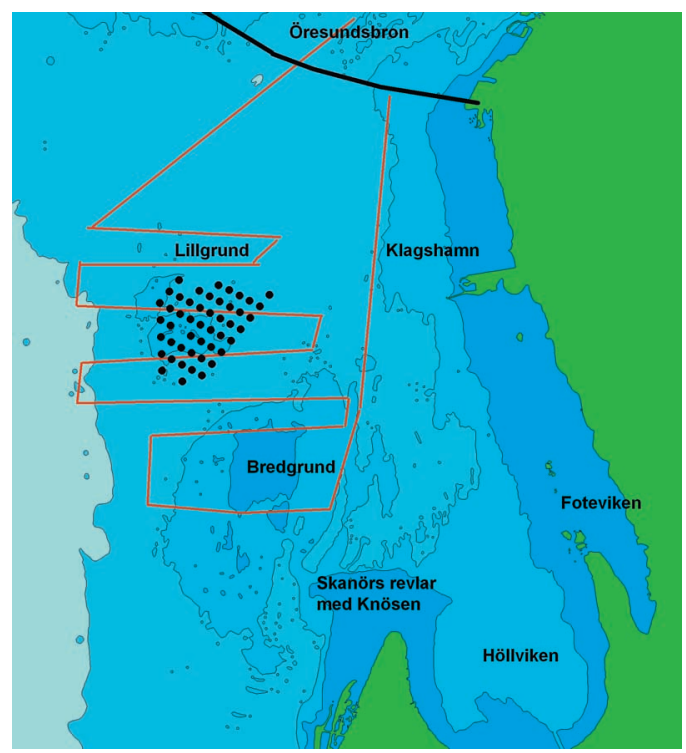

Figure 2. Map of the northern part of the study area in Öresund with the boat survey lines shown in red. Water depths are shown with different grades of blue: $0-3 \mathrm{~m}$ (darkest), 3-6 $\mathrm{m}, 6-10 \mathrm{~m}$ and $10-20 \mathrm{~m}$ (lightest). The wind turbines at Lillgrund are shown with black dots.

Karta över norra delen av undersökningsområdet $i$ Öresund med den standardiserade rutten för båtinventeringarna inritad i rött. Vindkraftverken visas med svarta punkter. De olika blå nyanserna visar områden med olika djup med de fyra djupintervallen 0-3 m (mörkast blått), 3-6 m, 6-10 m och 10-20 m och djupare (ljusast). 
we divided the study area in a northern and a southern part (Figure 1). The northern part, from the Öresund Bridge in the north down to Bredgrund in the south, roughly corresponds to the area covered by the boat surveys, (Figure $1 \& 2$ ). The southern part consisted of the areas west and south of Falsterbo peninsula (Figure 1).

The bottom substrate as well as the submerged vegetation and benthic fauna of the area is well documented in studies covering the whole area of southern Öresund from Landskrona to south of Falsterbo made in connection with the establishment of the Öresund Bridge north of Lillgrund. Large areas of Zostera vegetation are found in the area (Semac 1997); these areas are important for many benthic organisms and thus important as feeding areas for several water birds (Nilsson 1972). The benthic fauna showed high biomasses and the coverage by blue mussels Mytilus edulis was around $40 \%$ in the areas between the Öresund Bridge and Falsterbo (Semac 1997, 1998). Similarly, there were extensive Zostera beds in the shallower areas south of Falsterbo and large stony shallows further out with dense populations of blue mussels. The area has apparently large capacities as feeding areas for Eiders Somateria mollissima and other diving ducks.

\section{Methods}

Bird surveys were made both from the air and from boat. With aerial surveys (Figure 1) it was possible to cover the whole area including the parts south of Falsterbo, whereas boat surveys were used for a more detailed coverage of the northern parts around Lillgrund. In both cases we used a transect approach where birds were recorded along predetermined lines. During aerial surveys birds were counted within a small strip around the lines, and total bird numbers were calculated based on number of counted birds and total area, assuming that bird density recorded along the transect lines were representative of areas outside of the transects. During boat surveys all birds seen, irrespective of distance from the boat, were counted and hence counted bird numbers equal total numbers for the area covered.

Aerial surveys were conducted from a CESSNA 337 Skymaster, a high-winged twin-engine aircraft with good visibility for the observers. Two observers were always used during each survey, each covering one side of the aircraft. The flight speed of the aircraft was about $180 \mathrm{~km} / \mathrm{h}$ and we flew the surveys at an altitude of 50-70 m above sea level.
Observations were registered on tape or digital recorder and the position of the aircraft was continuously stored by GPS.

The survey lines were separated by two $\mathrm{km}$. The observers counted birds present within $200 \mathrm{~m}$ on each side of the aircraft. There is an $80 \mathrm{~m}$ wide zone $(40+40 \mathrm{~m})$ just under the aircraft that is not visible for the observers. Subtracting this "dead zone" from the surveyed belt $(200+200 \mathrm{~m})$ makes the sector covered $320 \mathrm{~m}$ wide in total. Calculations of total numbers of waterbirds in the study area during the counts were done by multiplying the number of counted birds within the surveyed belt with a factor of $6.25(6.25 \times 320 \mathrm{~m}=2000 \mathrm{~m}=$ $1 \mathrm{~km}$ on each side of the line).

A total of 16 survey lines were used throughout the surveys (Figure 1). After the construction of the wind farm, survey lines 3 and 4 were modified so that they passed from SE to NW through the windfarm.

In all, 22 aerial surveys were made 2004-2011, 14 in winter (December-mid-March) and eight in spring (mid-March-May). The general aim was to conduct one survey per month in the period December-May in the covered years. Gaps in the coverage of aerial surveys were due to difficult weather conditions. No aerial surveys were made in the years 2001-2003 since there was no suitable aircraft available in the region during that period.

Boat surveys followed standardized methods recommended by the ESAS-project (European Seabird at Sea Team, Komdeur et al. 1992). The method was originally established for larger ships in offshore areas, but we did the surveys from a smaller boat (a $10 \mathrm{~m}$ long vessel with observation height about $3 \mathrm{~m}$ above the water surface) and adapted the method accordingly.

The standardized route during boat surveys went from the Öresund Bridge in the north, over Lillgrund and Bredgrund and back to the bridge (Figure 2 ). The distance between survey lines over Lillgrund were about $1.5 \mathrm{~km}$ whereas the distance between the two southernmost lines was little more than $2 \mathrm{~km}$, due to shallow water. We do not think that this affected the numbers of observed birds to any larger extent, although single birds of smaller species may have been missed in the latter case. The surveys were normally conducted by two observers, each covering one side of the boat. Some counts had to be made with only one observer (covering just one side). In such cases total numbers have been calculated by simply doubling the figures counted by the single observer.

During boat surveys all birds seen (irrespective 
of distance from the transect line) were counted and the position of each observation (bird or flock of birds) was estimated into five distance bands. The following bands were used: $A=0-50 \mathrm{~m}$, $\mathrm{B}=50-100 \mathrm{~m}, \mathrm{C}=100-200 \mathrm{~m}, \mathrm{D}=200-300 \mathrm{~m}$ and $\mathrm{E}>300 \mathrm{~m}$. The division of the data into different distance bands was used to avoid double-counting of birds, but not used in any calculations of density or total bird numbers. Instead we treated the data collected during boat surveys as a complete count of the area in question, based on our general impression that we actually observed all birds present, at least for larger species occurring in flocks (i.e. all sea ducks). Observations were registered on tape or digital recorder with time of observation, species, number of individuals, behaviour and estimated position (= distance band). The position of the boat was recorded with a GPS every minute, meaning that a position was recorded about every $170 \mathrm{~m}$ with the normal travelling speed $(10 \mathrm{~km} / \mathrm{h})$.

In all, we made 20 boat surveys 2001-2011, 13 in winter and seven in spring. As for the aerial surveys, the general aim was to conduct one survey per month during winter and spring in the covered years. This turned out to be impossible for practical reasons. Technical problems with the boat prevented surveys during some periods and in the unusually cold winters 2009/2010 and 2010/2011 the ice situation in the Öresund stopped the boat from getting out of the harbour for longer periods. A few boat surveys were also made during other parts of the year (i.e. autumn), but bird numbers recorded during those were generally low and here we focus on results during the time of the year when we have data both from boat and aerial surveys.

\section{Results}

Long-tailed Duck Clangula hyemalis

The mean winter numbers for the entire study area was 2010 birds, and the corresponding spring average was 2291 individuals (Table 1). Numbers present did however vary greatly between different surveys, ranging between 500 and almost 7000 in winter and early spring (Figure 3 ).

Both the aerial and boat surveys showed the same general time pattern over the season with relatively low numbers present in December a fairly constant average level, but high variation, during Januaryearly spring followed by rapidly dropping numbers in April. Very few Long-tailed Ducks were seen in May (Figure 4).

Long-tailed Ducks were foremost seen in the areas west and south of Falsterbo peninsula. The southern parts held about $80-90 \%$ of all individuals both in winter and in spring (Figure 5, Table 1). The maps show a tendency for a more spread out distribution in winter, with the southern parts being slightly more important in spring. Numbers recorded during boat surveys (Figure 4) confirm the relatively small importance of the northern parts of the area for Long-tailed Ducks. Within both subareas the Long-tailed Ducks were found in small flocks, and no larger concentrations (flocks of $>100$ birds) were registered (Figure 5, 6).

\section{Velvet Scoter Melanitta fusca}

Velvet scoters were found in small numbers; average numbers present were 191 during winter and 120 for the spring season (Figure 7, Table 1). Variation between surveys was large, ranging between a few tens and $>500$ birds between December and April (Figure 7).

Table 1. Average estimated total numbers of sea ducks from winter (14) and spring (8) surveys in offshore parts of southern Swedish Öresund (data from aerial surveys, see Figure 1). The proportions seen in the southern and northern part of the study area are also shown.

Medelantal beräknade havslevande dykänder vid inventeringar under vinter (14) och vår (8) i utsjödelarna av södra svenska Öresund 2004-2011 (från flyginventeringsdata, se Figur 1). Den procentuella fördelningen mellan södra resp. norra delen av undersökningsområdet visas också.

\begin{tabular}{llrrl}
\hline Species & Season & Mean & \% South & \% North \\
\hline Long-tailed Duck Clangula hyemalis & Winter & 2010 & 81 & 19 \\
& Spring & 2291 & 88 & 12 \\
Velvet Scoter Melanitta fusca & Winter & 191 & 100 & 0 \\
& Spring & 120 & 100 & 0 \\
Common Scoter Melanitta nigra & Winter & 1254 & 100 & 0 \\
& Spring & 693 & 100 & 0 \\
Common Eider Somateria mollissima & Winter & 12383 & 84 & 16 \\
& Spring & 14906 & 52 & 48 \\
Red-breasted Merganser Mergus serrator & Winter & 3972 & 14 & 86 \\
& Spring & 1224 & 23 & 77 \\
\hline
\end{tabular}



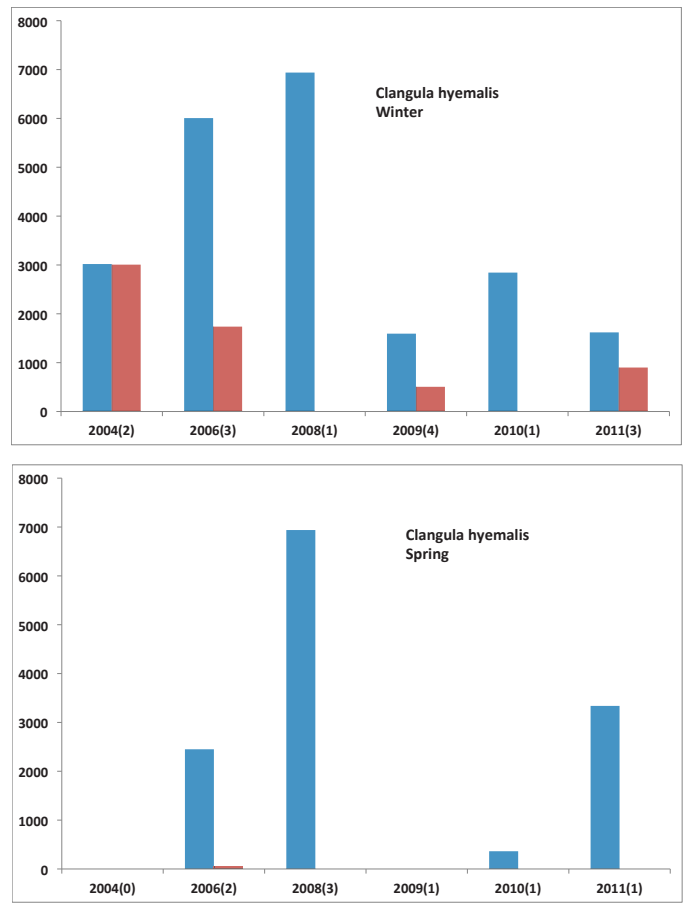

Figure 3. Estimated maximum and minimum numbers of Long-tailed Ducks Clangula hyemalis in the study area during different years in winter and spring. Number of aerial surveys shown in brackets.

Beräknade maximi och minimiantal för alfågel Clangula hyemalis $i$ undersökningsområdet under olika år fördelat på vinter och vår. Antalet flyginventeringar anges inom parentes.

The highest numbers were recorded in January and March, but it is hard to see a regular pattern in the occurrence. If anything, numbers were higher in December-January, lower in February and then higher again in March. Only low numbers were seen in April and no birds at all were observed in May (Figure 8).

The species was almost exclusively observed in the southern part of the area (Table 1). No Velvet Scoters were seen in the northern area during aerial surveys, but a few individuals were recorded during boat surveys. Within the southern area most Velvet Scoters were seen south of Falsterbo peninsula (Figure 9). No larger flocks ( $>25$ birds) or concentrations of the species were recorded.

\section{Common Scoter Melanitta nigra}

Common Scoters were generally more numerous than Velvet Scoters; the winter average was 1254 and the spring average 693 individuals (Table 1). As for the other sea ducks, numbers showed a large variation between surveys, ranging between just a
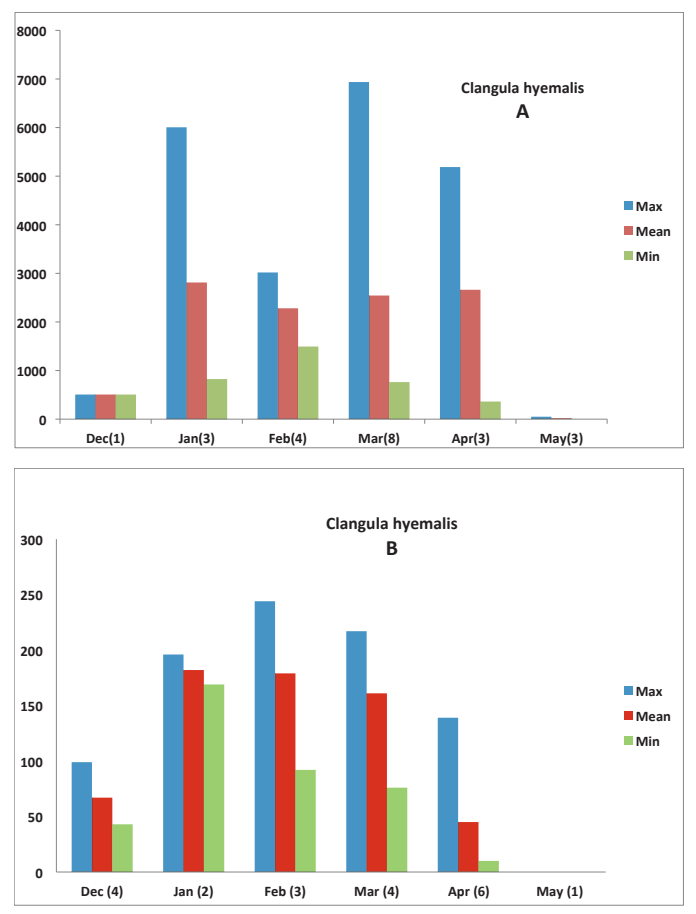

Figure 4. Maximum, minimum and average numbers of Long-tailed Ducks Clangula hyemalis in the study area during different months. a) estimated numbers from aerial surveys, b) observed numbers from boat surevys. Number of surveys shown in brackets.

Maximi, minimi och medelantal för alfågel Clangula hyemalis $i$ undersökningsområdet under olika månader. a) beräknade värden från flyginventeringar, b) inräknade antal från båtinventeringar. Antalet inventeringstillfällen anges inom parentes.

few tens up to $>5500$ individuals during a single survey (Figure 10).

The time pattern showed some resemblance to the one outlined above for Velvet Scoter, with high maximum numbers recorded in early winter and late winter to early spring, and lower numbers in February, in between these (Figure11).

Also, Common Scoters were almost exclusively recorded in the southern part of the study area. Only a few birds were occasionally seen in the northern parts, both during air and boat surveys (Figure 12, Table 1). The scoters (both species) were showing the most aggregated distribution and all larger flocks were recorded in the shallow parts south of Falsterbo peninsula (Figure 12). Common Scoters were present in flocks of up to 250 individuals. 

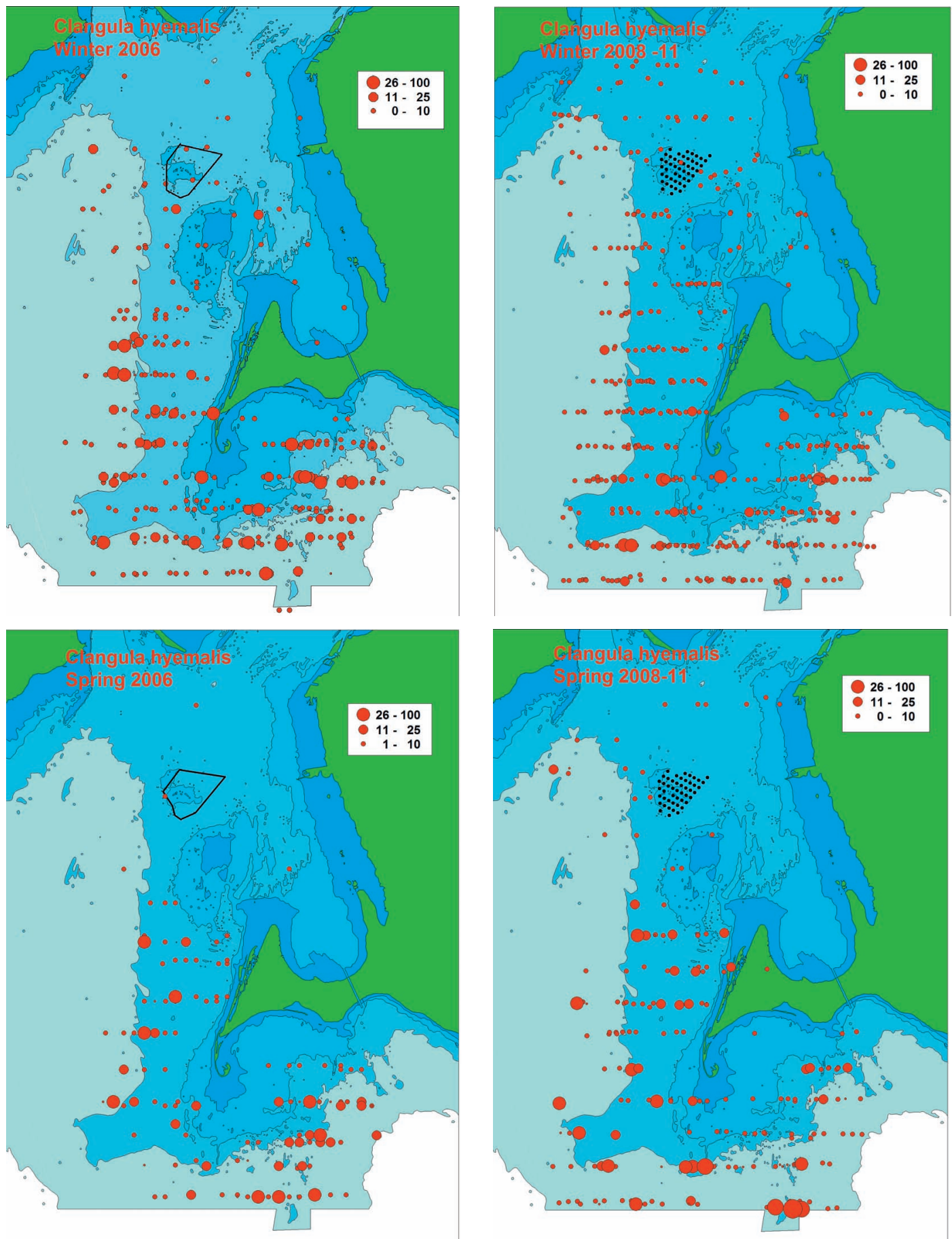

Figure 5. Summary distribution maps for winter and spring for the Long-tailed Duck Clangula hyemalis from aerial surveys 2006 (left) and 2008-2011 (right) for the winter and spring seasons.

Sammanfattande utbredningskartor vinter och vår för alfågel Clangula hyemalis från flyginventeringar 2006 (vänster) och 2008-2011 (höger). 

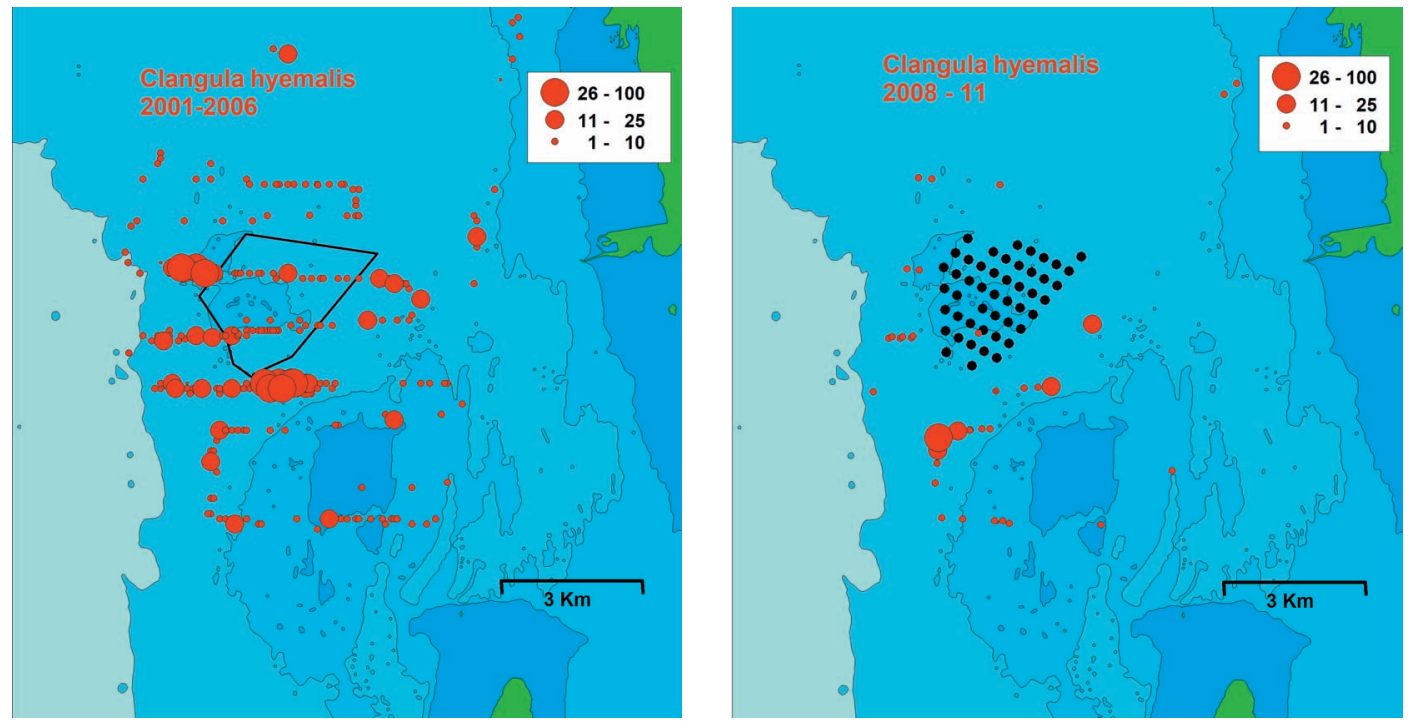

Figure 6. Summary distribution maps for the Long-tailed Duck Clangula hyemalis from boat surveys 2001-2006 (left) and 2008-2011 (right).

Sammanfattande utbredningskartor för alfågel Clangula hyemalis från båtinventeringar 2001-2006 (vänster) och 2008 -2011 (höger).

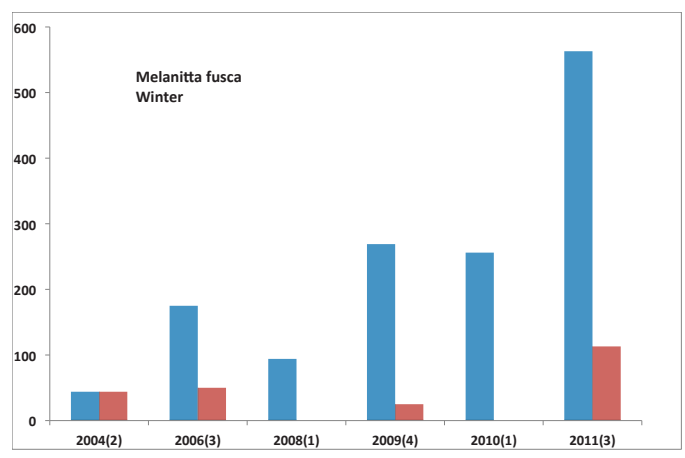

Figure 7. Estimated maximum and minimum numbers of Velvet Scoters Melanitta fusca in the study area during different years in winter. Number of aerial surveys shown in brackets.

Beräknade maximi och minimiantal för svärta Melanitta fusca $i$ undersökningsområdet under olika år. Antalet flyginventeringar anges inom parentes.

\section{Common Eider Somateria mollissima}

The Eider was the most common sea duck in the area. The overall averages for the whole area were $>12000$ individuals in winter and almost 15000 birds in spring (Table 1). There was variation between surveys with numbers ranging between 6500 and 19000 in the winter, and between 4000 and 47600 in spring (Figure 13). Variation was hence much more marked during spring.

The time pattern revealed rather stable numbers

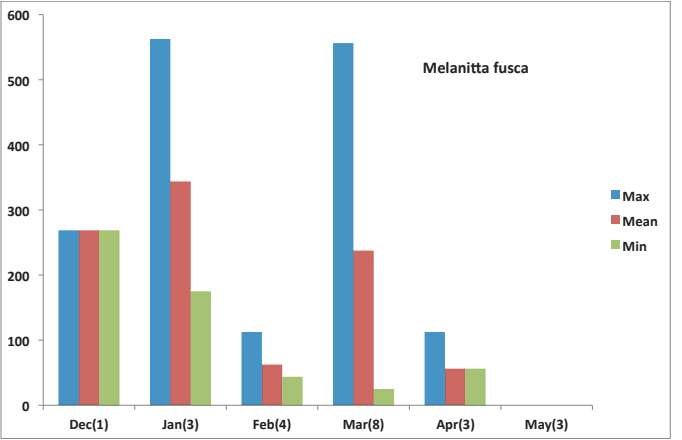

Figure 8. Estimated maximum, minimum and average numbers of Velvet Scoters Melanitta fusca in the study area during different months from aerial surveys. Number of surveys shown in brackets.

Beräknade maximi, minimi och medelantal för svärta Melanitta fusca $i$ undersökningsområdet under olika månader från flyginventeringar. Antalet inventeringstillfällen anges inom parentes.

of birds present through the winter with monthly averages between 12000 and 19000 birds. A distinct peak in maximum numbers then occurred during early spring, coinciding with the very marked peak of migration through the area in late Marchearly April. Good numbers, a few 1000, were still present in May (Figure 14).

Large numbers were recorded both in the south- 


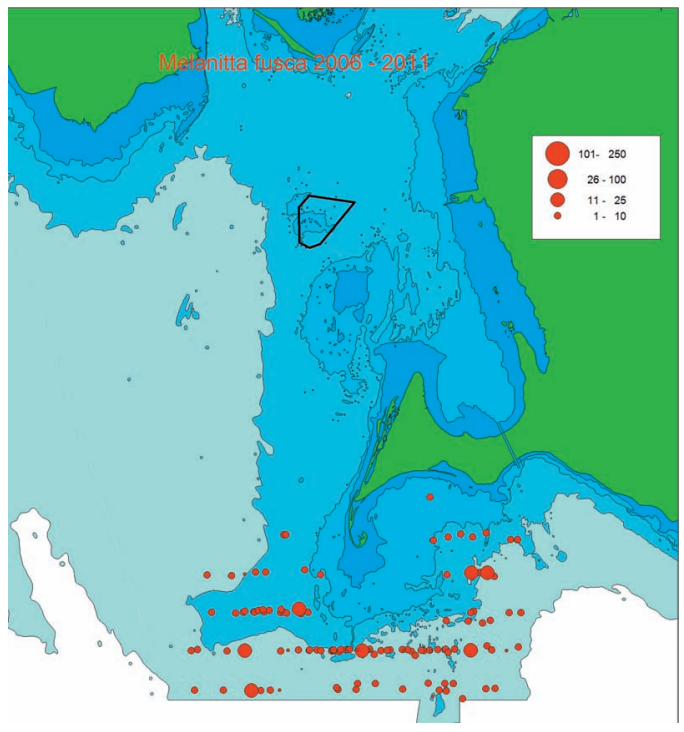

Figure 9. Summary distribution map for the Velvet Scoter Melanitta fusca from aerial surveys.

Sammanfattande utbredningskarta för svärta Melanitta fusca från flyginventeringar

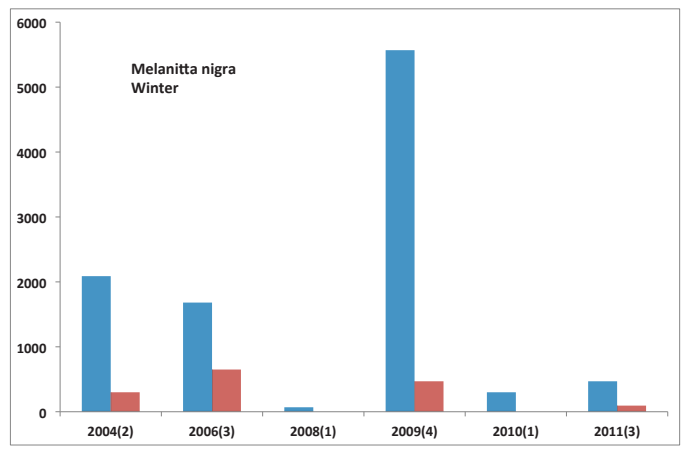

Figure. 10. Estimated maximum and minimum numbers of Common Scoters Melanitta nigra in the study area in winter during different years. Number of aerial surveys shown in brackets.

Beräknade maximi och minimi antal för sjöorre Melanitta nigra $i$ undersökningsområdet. Antalet inventeringar anges inom parentes.

ern and the northern parts, both in winter and in spring. The relative importance of the two parts did however differ between seasons, with the southern area, especially south of Falsterbo peninsula, being more important in winter, while the northern part had an almost equal importance as the shallow areas south of Falsterbo in spring (Figure 15, Table 1). Boat surveys corroborated this pattern with relatively low numbers being present in winter and

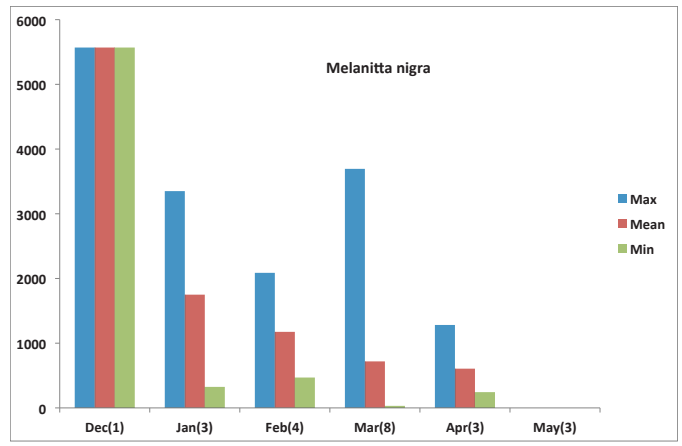

Figure 11. Estimated maximum, minimum and average numbers of Common Scoters Melanitta nigra in the study area during different months from aerial surveys. Number of surveys shown in brackets.

Beräknade maximi, minimi och medelantal för sjöorre Melanitta nigra $i$ undersökningsområdet under olika månader från flyginventeringar. Antalet inventeringstillfällen anges inom parentes.

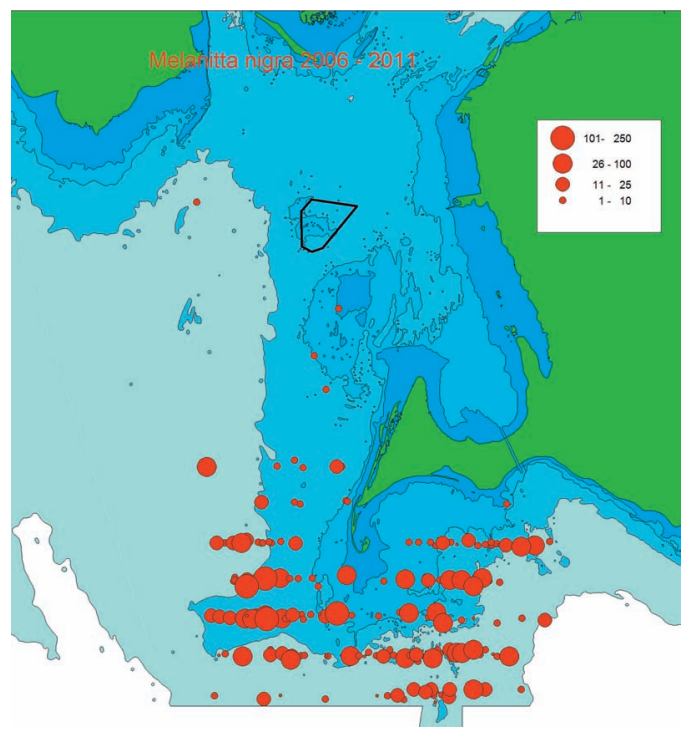

Figure 12. Summary distribution map for the Common Scoter Melanitta nigra from aerial surveys.

Sammanfattande utbredningskarta för sjöorre Melanitta nigra frän flyginventeringar.

much higher numbers in spring in the area covered by boat, the northern area (Figure 16). Large flocks of several hundred birds were seen well spread all over the study area in spring, but only south of Falsterbo in winter (Figure 15).

\section{Red-breasted merganser Mergus merganser}

The Red-breasted Merganser was the second most common sea duck in the area with a winter average 

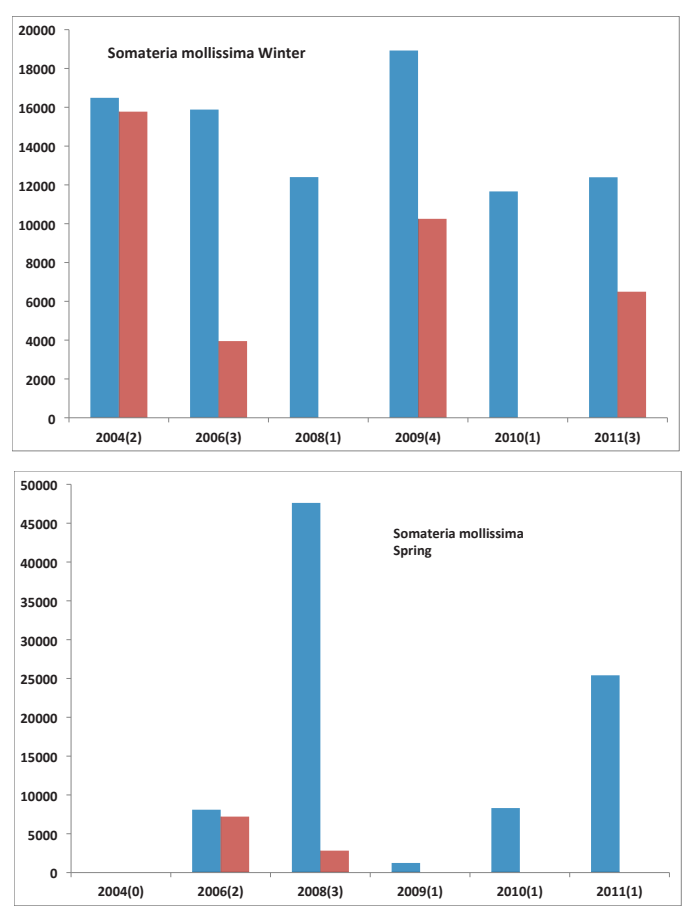

Figure 13. Estimated maximum and minimum numbers of Eiders Somateria mollissima in the study area during winter and spring. Number of aerial surveys shown in brackets. Beräknade maximi och minimiantal för ejder Somateria mollissima $i$ undersökningsområdet vinter och vår. Antalet inventeringar anges inom parentes.

of almost 4000 individuals and a spring mean of 1200 birds (Table 1). Numbers showed a marked variation between surveys, ranging from close to 2000 to more than 12000 birds in winter, and between a few tens and $>3000$ in spring (Figure17).

Both results from the air and from boat showed the same time patterns. Winter numbers were generally higher than spring numbers, with the highest average numbers recorded in January and February. Relatively good numbers were present already in December as well. Numbers then dropped rather dramatically during spring and in May only a few tens to a few hundred were recorded (Figure 18).

Unlike the other species, the northern parts were the most important for Red-breasted Mergansers. These parts were holding $86 \%$ in winter and $77 \%$ in spring (Table 1, Figure 19). The shallow areas south of Falsterbo peninsula were of relatively little importance during winter and spring. Instead, mergansers were concentrated to the parts between Bredgrund and the Öresund Bridge, i.e. the parts covered by the boat surveys (Figure 19, 20).
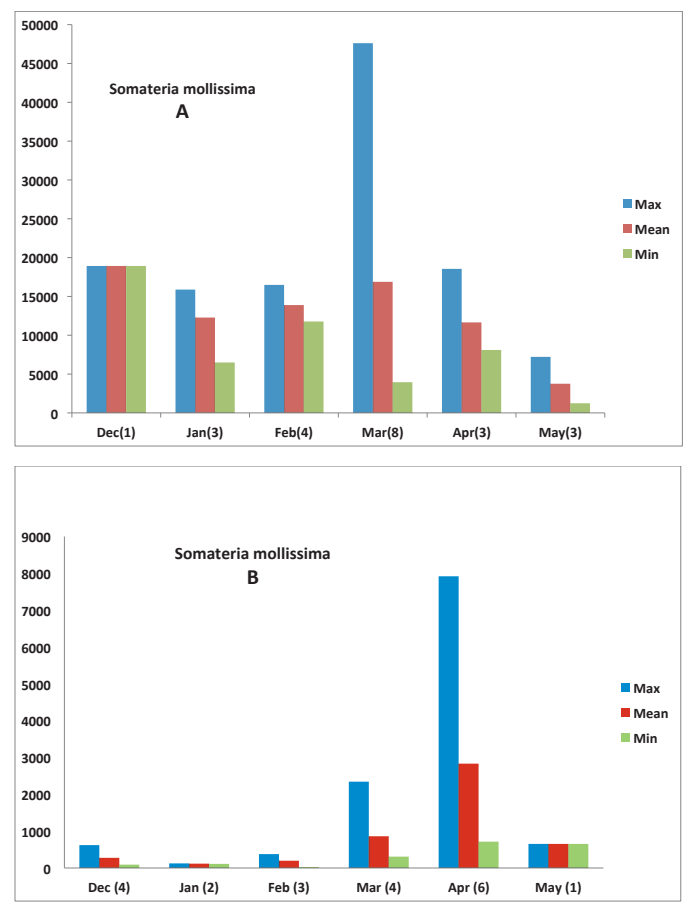

Figure 14. Maximum, minimum and average numbers of Eiders Somateria mollissima in the study area during different months. a) estimated numbers from aerial surveys, b) observed numbers from boat surevys. Number of surveys shown in brackets.

Maximi, minimi och medelantal för ejder Somateria mollissima $i$ undersökningsområdet under olika månader. a) beräknade värden från flyginventeringar, b) inräknade antal från båtinventeringar. Antalet inventeringstillfällen anges inom parentes.

\section{Discussion}

The main aim of this paper is to show the magnitude of sea duck use of the Swedish part of southern Öresund during winter and spring. Although the species composition and some of the general patterns were known, more exact numbers were not known previously. The number of birds found in this study can be compared with published figures for the whole of Sweden or/and the entire Baltic in order to elucidate the national and international importance of the area for these birds.

Here we use the " $1-\%$ criterion" to evaluate if the area is of importance in a wider perspective or not. Originally presented as one of the criteria for pin-pointing wetlands of international importance under the Ramsar convention (www.ramsar.org) this criterion states: "A wetland should be considered internationally important if it regularly supports $1 \%$ of the individuals in a population of one 

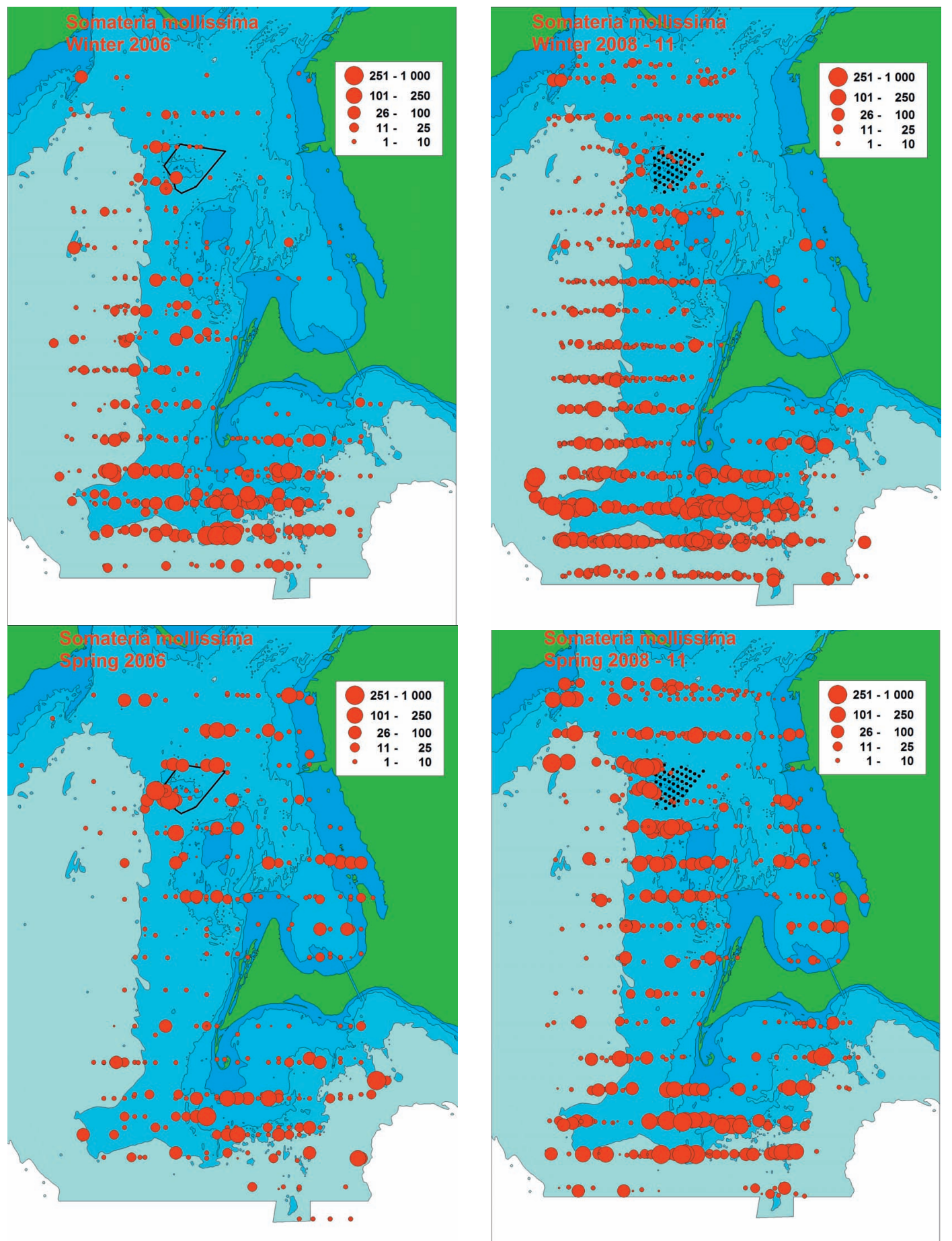

Figure 15. Summary distribution maps for the Eider Somateria mollissima from aerial surveys 2006 (left) and $2008-2011$ (right) for the winter and spring seasons.

Sammanfattande utbredningskartor vinter och vår för ejder Somateria mollissima från flyginventeringar 2006 (vänster) och 2008-2011(höger). 

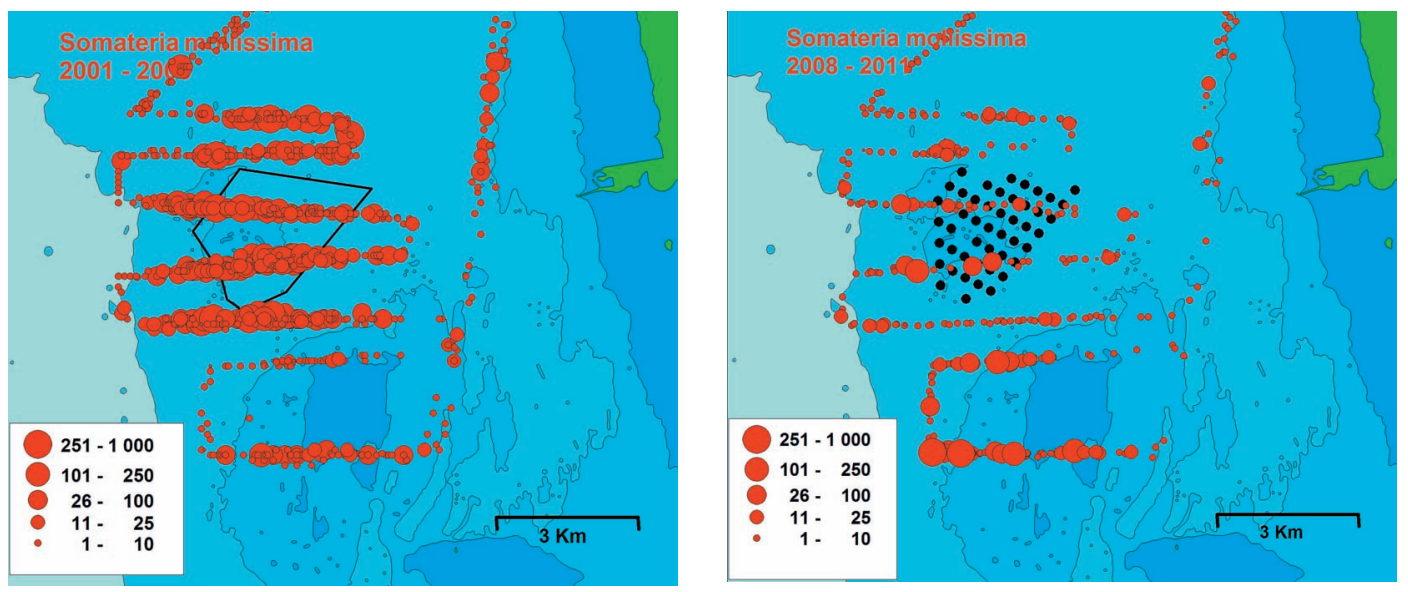

Figure 16. Summary distribution maps for the Eider Somateria mollissima from boat surveys 2001-2006 (left) and 2008-2011 (right).

Sammanfattande utbredningskartor för ejder Somateria mollissima från båtinventeringar 2001-2006 (vänster) och 20082011 (höger).
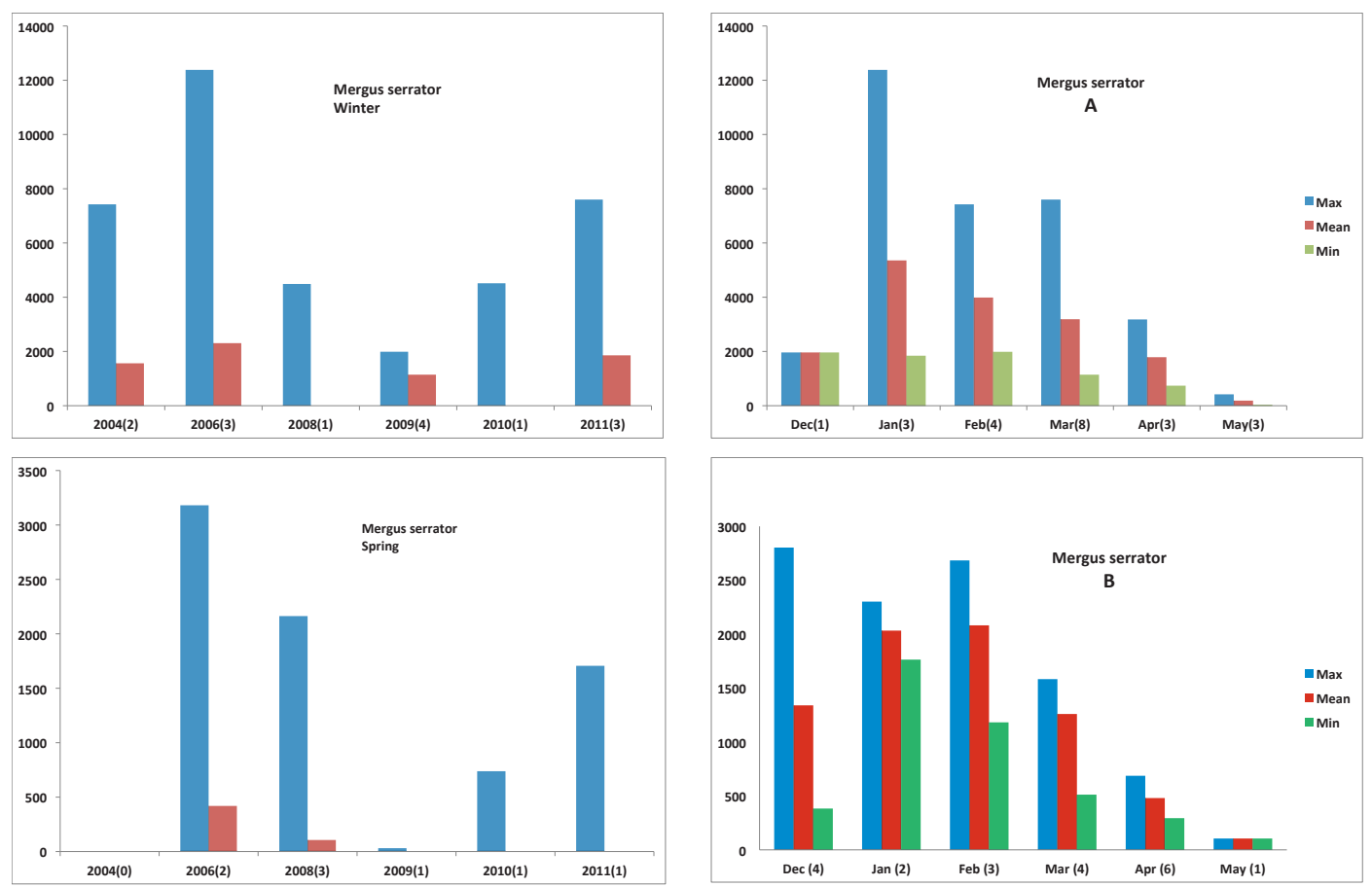

Figure 17. Estimated maximum and minimum numbers of Red-breasted Mergansers Mergus serrator in the study area during different years in winter and spring. Number of aerial surveys shown in brackets.

Beräknade maximi och minimi antal för småskrake Mergus serrator $i$ undersökningsområdet under olika år fördelat på vinter och vår. Antalet inventeringar anges inom parentes.

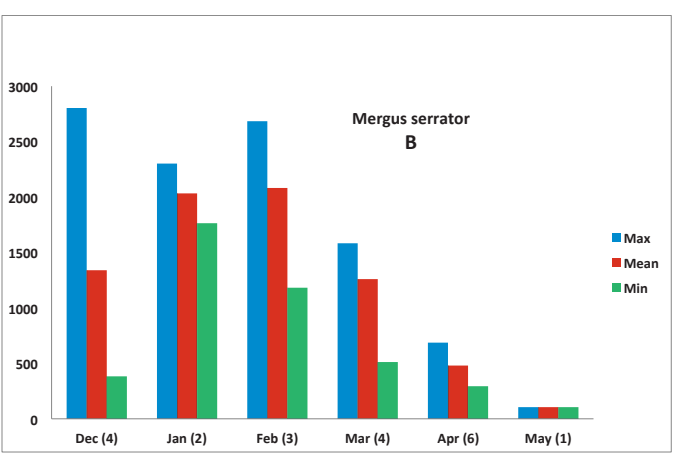

Figure 18. Maximum, minimum and average numbers of Red-breasted Mergansers Mergus serrator in the study area during different months. a) estimated numbers from aerial surveys, b) observed numbers from boat surevys. Number of surveys shown in brackets.

Maximi, minimi och medelantal för småskrake Mergus serrator $i$ undersökningsområdet under olika månader. a) beräknade värden från flyginventeringar, b) inräknade antal från båtinventeringar. Antalet inventeringstillfällen anges inom parentes. 

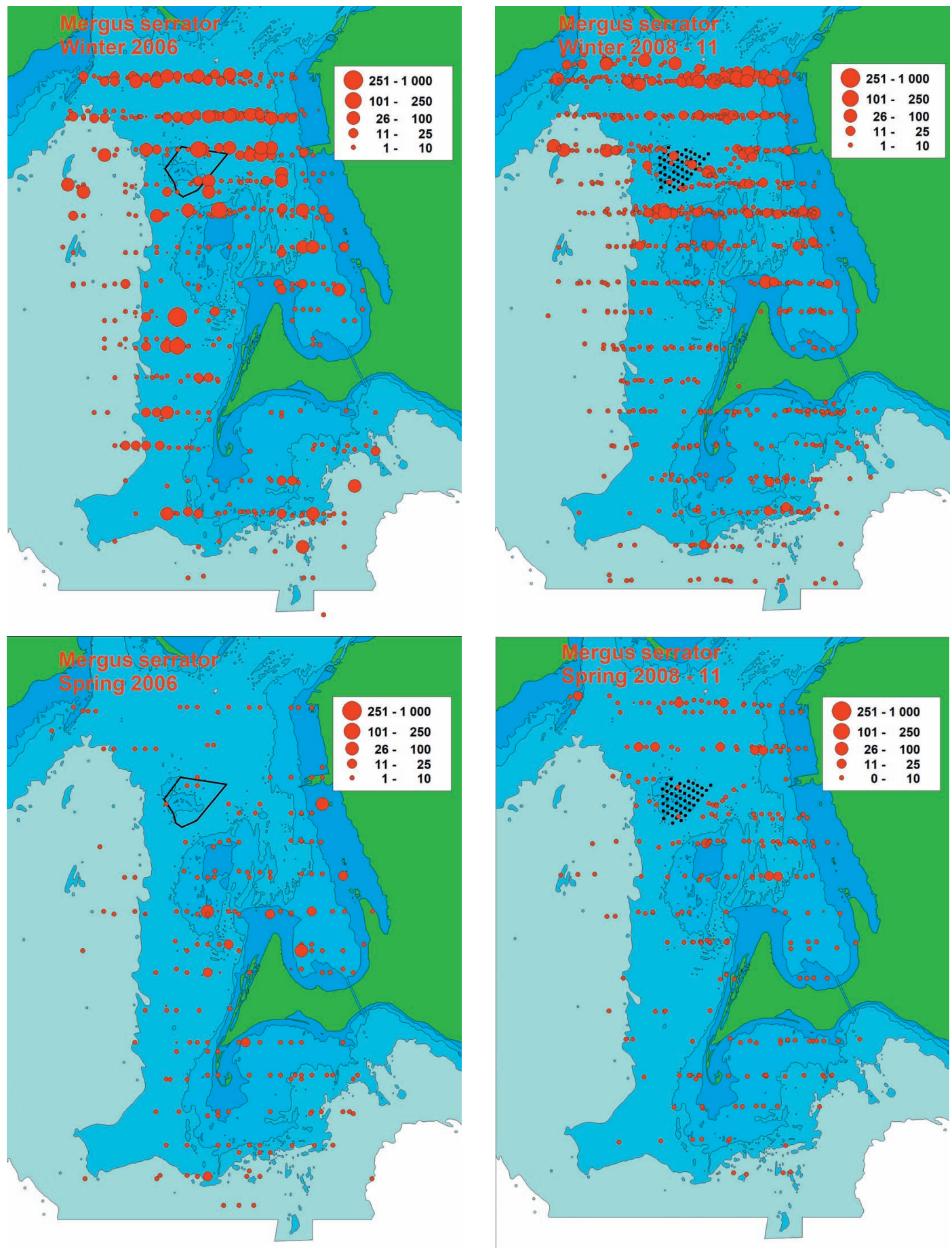

Figure 19. Summary distribution maps for winter and spring for the Red-breasted Merganser Mergus serrator from aerial surveys 2006 (left) and 2008-2011 (right).

Sammanfattande utbredningskartor vinter och vår för småskrake Mergus serrator från flyginventeringar 2006 (vänster) och 2008-2011(höger). 

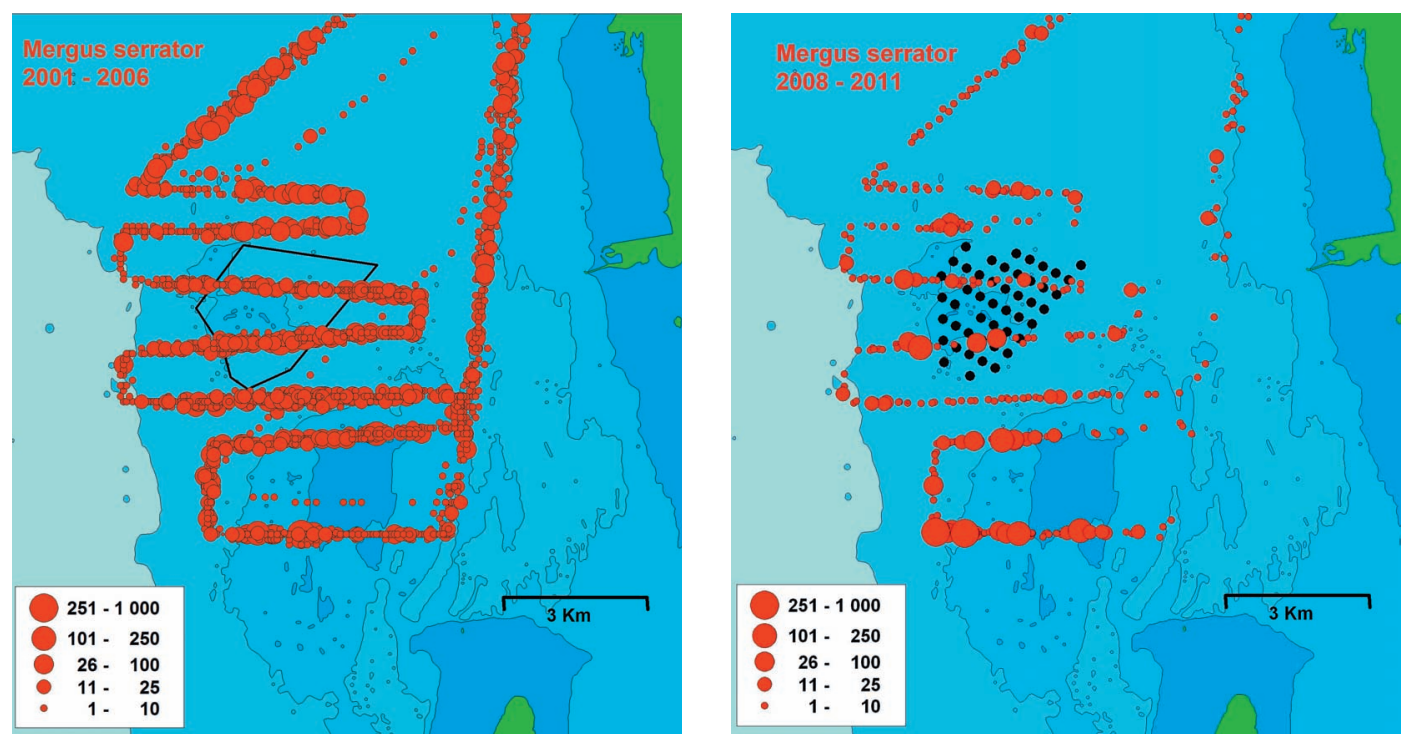

Figure 20. Summary distribution maps for the Red-breasted Merganser Mergus serrator from boat surveys 2001-2006 (left) and 2008-2011 (right).

Sammanfattande utbredningskartor för småskrake Mergus serrator från båtinventeringar 2001-2006 (vänster) och 20082011 (höger).

species or subspecies of waterbird" (Delany \& Scott 2006). We compare average and maximum numbers found by us with overall numbers for all of Sweden (winter only) from Nilsson (2012) and for the whole Baltic (winter and spring numbers) (Skov et al. 2011) in order to see if more than 1\% of the populations in question (Swedish and Baltic wintering numbers) use southern Öresund. If so, we regard southern Öresund as nationally (Sweden) or internationally (Baltic) important for the species in question. Both sources refer to numbers collected during the SOWBAS-project in 2007-2009 (Skov et al 2011). The Baltic in this case include the waters of Kattegat and the Danish straits.). Note that published totals for Sweden are based on surveys made with exactly the same methods as in this study, i.e. aerial surveys conducted by exactly the same field personnel and the same aircraft (Nilsson 2012), making these figures directly comparable. International numbers from Skov et al. (2011) are modelled numbers based on several different data sources, including land-based counts, ship- and air-based surveys but should still be comparable on a general level. In both cases these methods yield underestimates of true abundance, something that will not affect the comparisons and the conclusions.

Southern Öresund is not of any higher regular importance for wintering or spring staging Long- tailed Ducks. Average numbers in winter constitute $<0.5 \%$ of the present Swedish wintering population of around 500000 birds (Nilsson 2012). Maximum numbers found do however reach $1.4 \%$ of the Swedish winter population, but our surveys indicate that this is not a regular phenomenon. From an international perspective the area is of even lower importance and both average and maximum numbers found in the area do not exceed $0.5 \%$ of the Baltic wintering population of around 1,5 million birds (Skov et al. 2011).

Even though numbers of recorded Velvet Scoters in the area were low, these still constitute between $1.7 \%$ and $6.4 \%$ of the Swedish wintering population of 3000-7000 birds (Nilsson 2012). Maximum numbers make up $7.1-16.7 \%$ of the wintering Swedish birds. Hence, southern Öresund is of national importance as a wintering area for Velvet Scoters. From an international perspective the area is of limited importance as only about $0.1 \%$ of the total Baltic winter population of 373000 birds (Skov et al. 2011) was found here.

The area is also of national importance for wintering Common Scoters as between $1.3 \%$ and $6.3 \%$ of the national wintering numbers of 20000 55000 birds (Nilsson 2012) were found on average. Maximum numbers show an even higher importance in some years with up to $27.5 \%$ of the Swedish winter population. The international im- 
portance is on average low, around $0.1 \%$ of the total Baltic winter population of 412000 (Skov et al. 2011), but peak numbers may reach international importance, $1.3 \%$.

Southern Öresund is very important for Common Eiders both during winter and spring. Average winter numbers found here make up $17.2 \%$ of the 72000 wintering Eiders in Sweden (Nilsson 2012). Maximum numbers in winter constitute $26.4 \%$ of the birds wintering in Swedish waters. Southern Öresund is also of international importance for wintering Eiders as average numbers found make up $2.4 \%$ of the 515000 Baltic wintering birds (Skov et al. 2011). Peak numbers in winter make up $3.7 \%$ of the Baltic wintering Eiders. Spring numbers on average make up $1.5 \%$ of the Baltic winter birds, while up to $9.2 \%$ were found during peak counts. Spring numbers using the area show a huge variation due to when the surveys were made in relation to the migration peak. Most birds in some years are probably only using the area for a short time as they are on their way towards Baltic breeding grounds. Numbers are also influenced by the large breeding colony at Saltholm (4800 nests in 2010; Christensen \& Bregnballe 2011), which is situated a short distance to the north of Lillgrund. This influence is of a more regular kind as breeding birds use nearby Swedish waters for foraging.

The Red-breasted Merganser is the hardest species of the sea ducks found in the area to evaluate in this way as data on overall populations are much less reliable than for the other species. This is primarily due to the fact that mergansers are harder to count during surveys from the air. Nilsson (2012) reports 8000 birds in Swedish waters outside of the west coast, but including Öresund, in 2009 which means that the overall population probably exceeded 10000 birds in that winter. Skov et al. (2011) reported 25700 birds for the whole Baltic. Using these figures, winter numbers in Öresund reach $39.7 \%$ of the Swedish winter population. Peak numbers recorded in Öresund even exceed the national total $(120 \%)$ ! The latter is of course a result of that winter numbers vary, and in that particular year when peak numbers were recorded in Öresund (2006), national numbers must have been much higher than the figure presented by Nilsson (2012). In any case, the conclusion is still that the area is of supreme national importance for winter Red-breasted Mergansers. The area is also of large international importance for the species. Average winter numbers constitute $15.5 \%$ of the Baltic wintering population, peak numbers $46.7 \%$. The area is also of international importance in spring with on average $4.8 \%$ of the Baltic wintering birds. Peak numbers in spring reach $11.7 \%$ of the Baltic winter population.

The conclusion from this exercise is that southern Öresund is of large importance both on national and international level for wintering and spring staging sea ducks, especially for Common Eiders and Red-breasted Mergansers.

Unfortunately few surveys of this area are available for earlier years so we cannot fully evaluate if use of southern Öresund has changed in any way up until our study period. A few boat transects were made in the waters around Falsterbo in the 1960s, yielding similar densities of Long-tailed Ducks as found in the present study (Nilsson 1972, 1980). In contrast to this the number of Long-tailed Ducks counted from the shore along the south coast of Scania, i.e. the area just to the east of the present study area, showed a marked decrease during the same period (Nilsson 2005, 2012). The decrease in the wintering population of Long-tailed Ducks along the south coast reflects the general decrease in the wintering numbers of this species in the Baltic (Skov et al. 2011). An analysis of the available surveys from Swedish waters showed a more varying picture (Nilsson 2012). Numbers wintering in some areas such as Hanöbukten and in the archipelagos of the east coast were similar to the ones recorded in the 1970s. The same seem to apply to the small wintering population in the offshore waters of Falsterbo.

The early surveys also identified the waters around Falsterbo as an important area for the Velvet Scoter and Common Scoter (Nilsson 1972), but as for the Red-breasted Merganser it was not possible to estimate overall numbers using the area at that time. In contrast to the present survey, the Velvet Scoter was more numerous than the Common Scoter in that period.

The Eider was not specifically included in the earlier studies (Nilsson 1972) but counts from the boat surveys south of Falsterbo and in the southern Öresund show that the area was used by large numbers also in those years (Nilsson unpubl.). Numbers seen from the survey lines were lower than during the present survey, but it should be remembered that the wintering Eider population has increased at least three-fold during the years between the surveys (Nilsson 2008). The main sites for the Eider during winter (and spring) in those years were the same as in the present study.

The earlier studies (Nilsson 1972) identified the waters south of Bredgrund as an important concentration area for the Red-breasted Mergansers but 
it was not possible to estimate the overall size of the population wintering in the area at that time. Counts from the shore both on the south coast of Scania and in the southern part of the Öresund show a marked variation but a clearly increasing trend in wintering numbers for the species from the 1970s until today (Nilsson 2005, 2008).

\section{References}

Delany, S. \& Scott, D. eds. 2006. Waterbird population estiumates. Fourth Edition. Wetlands International, Wageningen, The Netherlands

Christensen, T.K. \& Bregnballe, T. 2011. Status of the Danish breeding population of Eiders Somateria mollissima 2010. Dansk Ornitologisk Forenings Tidsskrift 105: 195-205.

Green, M. \& Nilsson, L. 2006. Fågelförekomsten vid Lillgrund, Södra Öresund 2001-06. En förstudie inför etablering av vindkraft till havs. Rapport. Ekologiska Institutionen, Lunds Universitet, Lund.

Komdeur, J., Bertelsen, J. \& Cracknell, G. 1992. Manual for Aeroplane and Ship Surveys of Waterfowl and Seabirds. IWRB Special Publication No. 19, Slimbridge, UK, 37 pp.

Nilsson, L. 1972. Habitat Selection, Food Choice and Feeding Habits of Diving Ducks in Coastal Waters of South Sweden during the Non-breeding Season. Ornis Scandinavica 3: 55-78.

Nilsson, L. 1980. De övervintrande alfåglarnas Clangula hyemalis antal och utbredning längs den svenska kusten. Vår Fågelvärld 39: 1-14.

Nilsson, L. 1996. Resting and wintering waterfowl along the Swedish coast of Öresund 1962-1995. Report to Öresundskonsortiet, Ecological Institute, University of Lund.

Nilsson, L. 2001. Möjlig påverkan på fågelfaunan av en vindkraftpark på Lillgrund, Öresund. Rapport, Ekologiska Institutionen, Lunds Universitet.

Nilsson, L. 2005. Forty years of midwinter counts along the coasts of Scania, south Sweden, 1964-2003. Ornis Svecica $15 ; 127-148$

Nilsson, L. 2008. Changes of numbers and distribution of wintering waterfowl in Sweden during forty years, 19672006. Ornis Svecica 18: 135-226.

Nilsson, L. 2012. Distribution and numbers of wintering sea ducks in Swedish offshore waters. Ornis Svecica 22: 39-60.

Nilsson, L. \& Green, M. 2002. Fågelkollisioner med Öresundsbron. Rapport från Ekologiska Institutionen, Lunds Universitet.

Nilsson, L. \& Green, M. 2011. Birds in southern Öresund in relation to the windfarm at Lillgrund. Final report of the monitoring program 2001-2011. Rapport från Biologiska Institutionen, Lunds Universitet.

Semac, J.V. 1997. The Authorities Control and Monitoring Programme for the Fixed Link across Öresund. Benthic vegetation. Zostera marina, Ruppia spp., Laminaria saccharina. Status Report 1996. Rapport till Öresundskonsortiet.

Semac, J.V. 1998. Myndigheternas kontrol- og overvågningsprogram for Öresundsforbindelsens kyst-til-kyst an- laeg. Blåmuslinger. Tillstandsrapport 1997. Rapport till Öresundskosortiet.

Skov, H., Heinänen, S., Zydelis, R., Bellebaum, J., Bzoma, S., Dagys, M., Durinck, J., Garthe, S., Grishanov, G., Hario, M., Kieckbusch, J.J., Kube, J., Kuresoo, A., Larsson, K., Luigujoe, L., Meissner, W., Nehls, H. W., Nilsson, L., Petersen, I.K., Roos, M.M., Pihl, S., Sonntag, N., Stock, A., Stipniece, A. \& Wahl, J. 2011. Waterbird Populations and Pressures in the Baltic Sea. Tema Nord 2011: 550.

Vattenfall Vindkraft. 2009. Lillgrund. Ett svenskt pilotprojekt inom havsbaserad vindkraft.

\section{Sammanfattning}

Södra Öresund utgör ett viktigt rast- och vinterområde för ett stort antal sjöfåglar. Saltholm på den danska sidan och kuststräckan Foteviken-Falsterbo samt delar av Lomma- och Lundåkrabukterna på den svenska sidan har utpekats som SPA-områden. Medan betydelsen av de grunda, strandnära områdena för fågelfaunan är väl dokumenterad, är informationen mer knapphändig vad gäller utsjöområdena. I denna uppsats utnyttjar vi inventeringsdata från kontrollprogrammet för Lillgrunds vindkraftpark för att belysa förekomsten av havslevande dykänder i utsjöområdena i södra Öresund åren 2001-2011. Lillgrunds vindkraftpark togs i drift senhösten 2007.

Programmet omfattade bl.a. flyg och båtinventeringar av rastande sjöfåglar i området (Figur 1 och 2). För att kunna jämföra fågelförekomsten inom olika delar, delades det område som täcktes med flyginventeringar i två delar, en sydlig och en nordlig del. Totalt genomfördes 22 flyginventeringar och 20 båtinventeringar under vinter och vår som en del av kontrollprogrammet. Både flyg och båtinventeringarna genomfördes som standardiserade linjetaxeringar, där fåglarna räknades inom bälten på vardera sidan om flygplanet resp. båten. Båtinventeringarna täckte själva vindkraftsparken samt dess närområde. Flyginventeringarna täckte däremot ett större område, dels kring själva vindkraftsparken, dels söder om Falsterbohalvön, som fick utgöra ett referensområde för att kunna följa eventuella förändringar i antal som inte kunde sättas i samband med vindkraftsparken. På basis av antalet individer inom flygräkningarnas inventeringsbälte och inventeringarnas täckningsgrad av undersökningsområdet har sedan totala antalet sjöfåglar av de olika arterna per inventering beräknats. 
Resultat

Fem arter av havslevande dykänder var vanligt förekommande i undersökningsområdet och behandlas närmare i uppsatsen: alfågel, svärta, sjöorre, ejder och småskrake. För varje art redovisas det beräknade antalet inom undersökningsområdet $\mathrm{i}$ tabell och diagram. Dessutom presenteras arternas utbredning i form av summakartor från flyg resp. båtinventeringarna.

Antalet alfåglar var i medeltal i undersökningsområdet 2010 för vinterinventeringarna och 2291 för våren, med en variation på mellan 500 och 7000 för olika inventeringstillfällen (Tabell 1, Figur 3). Relativt få alfåglar observerades i december och merparten lämnade senast i april (Figur 4). Merparten av alfåglarna (80-90\%), både under vinter och vår, var koncentrerade till området söder om Falsterbohalvön, medan den norra delen av undersökningsområdet var av mindre betydelse för arten (Figur 5, 6).

Svärtan observerades mest i ganska ringa antal, medelvärdena var 191 för vintern och 120 för våren, med en variation från några tiotal till mer än 500 (Tabell 1, Figur 7,8). Majoriteten av svärtorna observerades söder om Falsterbohalvön (Figur 9) med endast enstaka observerade i den norra delen av undersökningsområdet.

Sjöorren var vanligare än svärtan med i medeltal 1254 för vintern och 693 för våren. Antalet varierade från några tiotal till mer än 5500 (Tabell 1, Figur 10,11). Sjöorrarna var liksom svärtorna koncentrerade till farvattnen söder om Falsterbohalvön (Figur 12).

Ejdern var den vanligaste havsdykanden i området med i medeltal $>12000$ övervintrare och ca 15000 under våren, men med en betydande variation i antalet mellan olika inventeringar, särskilt under våren (Tabell 1, Figur 13,14). Några få tusen ejdrar kunde ses i området in i maj, vilket kan relateras till den stora häckningskolonin på Saltholm (Figur14). Som mest beräknades 47600 ejdrar för området vid en av inventeringarna under våren. Under vintern var ejdrarna talrikast söder om Falsterbohalvön, medan de var lika talrika i hela området vid vårinventeringarna (Figur 15,16).

Småskraken var den näst vanligaste havsdykanden i området. I medeltal beräknades antalet småskrakar i området till ca 4000 under vintern och 1200 under våren med som mest 12000 för vintern och >3000 för våren (Tabell 1, Figur 17, 18). Merparten av småskrakarna (77-86\%) förekom i den norra delen av området och de grunda områdena mellan Bredgrund och Öresundsbron (Figur 19, 20).

\section{Diskussion}

Ett huvudsyfte med denna presentation är att belysa områdets betydelse för de aktuella havslevande dykänderna. För denna utvärdering använder vi 1\% kriteriet enligt våtmarkskonventionen (www.ramsar.org ), som säger att ett område skall betraktas som ett internationellt viktigt område för arten när området regelbundet hyser men än $1 \%$ av det regionala beståndet. Vi jämför också fågelförekomsten i undersökningsområdet med de beräknade vinterbestånden för de svenska farvattnen och för hela Östersjön, vilket här också innefattar Kattegatt.

Södra Öresund (inkl. farvattnen söder om Falsterbo) utgör inget viktigt övervintringsområde eller vårrastområde för alfågel. Under vintern utgör medelantalet här $<0,5 \%$ av det svenska vinterbeståndet och även de högsta noterade antalen är låga jämfört med det samlade Östersjöbeståndet.

Beståndet av svärta under vintern är lågt jämfört med de internationella bestånden. Däremot kan området under vissa vintrar hysa mer än $25 \%$ av det ringa svenska vinterbeståndet. För sjöorren är bilden något annorlunda och de högsta antalen som räknats in i undersökningsområdet kan närma sig de internationella kriterierna, men medelantalet sjöorrar i området är lågt.

Ejdern utgjorde den vanligaste övervintrande havsdykanden i området och i medeltal fanns 17\% av det svenska vinterbeståndet på 72000 ejdrar (2009) här. Södra Öresund utgör också ett internationellt viktigt område för ejdern med i medeltal $2,4 \%$ av Östersjöns vinterbestånd. Vårsiffrorna kan vara höga och varierande och återspeglar till betydande del flyttningsrörelserna genom Öresund, men den stora kolonin på Saltholm är också av betydelse.

Undersökningsområdet är helt klart av stor betydelse för småskraken. Arten är svårinventerad och det är därför svårt att beräkna en nationell beståndsnivå, men området överskrider med god marginal kriterierna för en internationellt viktig lokal. Medelvärdet för området motsvarar ca $15 \%$ av det skattade vinterbeståndet för hela Östersjön. 